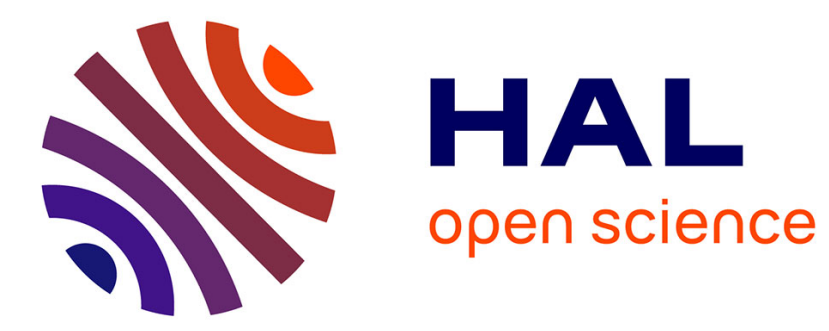

\title{
Post-breeding migration of four Long-tailed Skuas (Stercorarius longicaudus) from North and East Greenland to West Africa
}

\author{
Benoît Sittler, Adrian Aebischer, Olivier Gilg
}

\section{- To cite this version:}

Benoît Sittler, Adrian Aebischer, Olivier Gilg. Post-breeding migration of four Long-tailed Skuas (Stercorarius longicaudus) from North and East Greenland to West Africa. Journal für Ornithologie $=$ Journal of Ornithology, 2011, 152 (2), pp.375-381. 10.1007/s10336-010-0597-6 . hal-00637799

\author{
HAL Id: hal-00637799 \\ https://hal.science/hal-00637799
}

Submitted on 3 Nov 2011

HAL is a multi-disciplinary open access archive for the deposit and dissemination of scientific research documents, whether they are published or not. The documents may come from teaching and research institutions in France or abroad, or from public or private research centers.
L'archive ouverte pluridisciplinaire HAL, est destinée au dépôt et à la diffusion de documents scientifiques de niveau recherche, publiés ou non, émanant des établissements d'enseignement et de recherche français ou étrangers, des laboratoires publics ou privés. 
4 Benoît Sittler ${ }^{12}$, Adrian Aebischer ${ }^{13}$ and Olivier Gilg ${ }^{14}$

$5 \quad{ }^{1}$ Groupe de Recherche en Ecologie Arctique, 16 rue de Vernot, 21440 Francheville, France

$6 \quad{ }^{2}$ Institut für Landespflege, University of Freiburg, Tennenbacherstraße 4, 79106 Freiburg, Germany

${ }^{3}$ Museum of Natural History, Chemin du Musée 6, 1700 Fribourg, Switzerland

${ }^{4}$ Lab. Biogéosciences, UMR CNRS 5561, Université de Bourgogne, 21000 Dijon, France and Department of Biological and Environmental Sciences, University of Helsinki, 00014 Helsinki, Finland (corresponding author: olivier.gilg@gmail.com; tel/fax: +33 3803509 23).

Abstract

The Long-tailed Skua is a specialist predator of lemmings during summer and hence an important component of the Tundra ecosystems, but most of its life cycle takes place offshore and remains largely unknown outside of the breeding season. Using 9.5g solar-powered satellite transmitters, we could document for the first time the post-breeding movements of the Long-tailed Skua, from its highArctic breeding- grounds in North and Eastern Greenland, to the tropical waters of West Africa. The birds travelled the ca. $10.000 \mathrm{~km}$ of this migration in only 3-5 weeks, covering $800-900 \mathrm{~km} /$ day during active migration, which also occurred during night time. Leaving their breeding areas in August (except for one failed breeder), the Long-tailed Skuas first moved south along the coast of East Greenland towards a staging area off the Canadian Great Banks where they stayed for 1-3 weeks. From there, they crossed the Atlantic Ocean eastwards in just one week and entered the African waters near the Madeira Archipelago in September. Although we only monitored four birds for 1.5 to 3 months, migration routes were relatively similar between birds breeding in different locations and in different years.

Keywords

Satellite tracking, post-breeding migration, staging area, upwelling, rates of travel, Long-tailed Skua, Stercorarius longicaudus, Greenland. 
Der Zug von vier Falkenraubmöwen (Stercorarius longicaudus) von den Brutgebieten in Nord- und Ostgrönland bis nach Westafrika.

37 Falkenraubmöwen ernähren sich während der Brutzeit hauptsächlich von Lemmingen und

38 stellen somit ein wichtiges Glied in Tundren-Ökosystemen dar. Da sie aber den Großteil ihres

39 Lebens auf hoher See verbringen, ist über ihre Lebensweise außerhalb der Brutsaison nur

40 wenig bekannt. Mit Hilfe von $9.5 \mathrm{~g}$ schweren, solarbetriebenen Satellitensendern konnten

41 nun erstmals die Zugbewegungen von den hocharktischen Brutplätzen in Nord- und

42 Ostgrönland bis in die tropischen Gewässer vor der westafrikanischen Küste dokumentiert

43 werden. Innerhalb von 3 bis 5 Wochen legten die Vögel etwa 10000 km zurück. Die

44 Tagesetappen betrugen 800 bis $900 \mathrm{~km}$, wobei die Vögel auch nachts zogen. Nach dem

45 Verlassen der Brutgebiete im August flogen die Vögel zunächst entlang der

46 ostgrönländischen Küste bis zum Festlandsockel vor Neufundland, wo sie 1 bis 3 Wochen

47 blieben. Sie überquerten anschließend in nur einer Woche den Atlantik in südöstlicher

48 Richtung und gelangten über Madeira und die Kanaren bis in die Nähe der Kapverdischen

49 Inseln. Bislang konnten wir nur 4 Vögel über einen Zeitraum von 1.5 bis 3 Monate verfolgen,

50 jedoch wiesen die Zugrouten aus unterschiedlichen Brutgebieten in beiden

51 Untersuchungsjahren ähnliche Muster auf. 
54 The Long-tailed Skua (Stercorarius longicaudus) is an important component of the Arctic terrestrial 55 vertebrate community. Across most of its breeding range, it depends on cyclic lemming densities to breed (Andersson 1971, 1976, 1981; Larson 2007; Maher 1970; Meltofte and Høye 2007) and both species strongly interact (Gilg et al. 2003). Along with a few other predators, the Long-tailed Skua regulates the Collared Lemming (Dicrostonyx groenlandicus) dynamics in Northeast Greenland (Gilg et al. 2006; Schmidt et al. 2008), especially during the peak phase of the lemming cycle when, along with the Snowy Owl (Nyctea scandiaca) and the Arctic Fox (Alopex lagopus), it is responsible for the rapid summer decline in lemming numbers (Gilg 2002). assumed to impact their subsequent reproductive performance (Furness et al. 2006). De Korte (1985) has shown that Long-tailed Skuas breeding in Northeast Greenland arrive with maximal fat reserves in spring. The pelagic habitats they use during the non-breeding period (9-10 months of the year) must hence provide them with sufficient food resources to initiate breeding but are also, in turn, indirectly impacting the lemming population dynamics. Little is known, however, about the flyways and wintering grounds used by the species, the most pelagic of all Skuas (Furness 1987; Olsen and Larsson 1997). With the exception of some local concentrations reported from the Benguela upwelling (Lambert 1980; Ryan 1989), a cold nutrient rich current off the coasts of Namibia and South-Africa, there are nearly no ring recoveries for the species during the non-breeding period and flyways have been inferred from only a limited number of offshore observations.

Recent developments in satellite telemetry, with transmitters weighing less than $10 \mathrm{~g}$, have opened new perspectives for the study of medium sized bird (between 300 and 500g). Because it breeds in remote Arctic areas and spends the rest of the year in similarly remote offshore waters, the Long-tailed Skua is a perfect candidate species for these new research techniques. The present study presents the timing, duration, and flyways of four Greenlandic Long-tailed Skuas during their postbreeding migration, as part of a comprehensive long-term research of terrestrial vertebrates in Northeast Greenland (Gilg et al. 2003; Sittler 1995).

\section{$81 \quad$ Material and methods}

82 Four Long-tailed Skuas were captured and fitted with satellite transmitters (PTTs) in 2006 and 2007 in 83 the "North and East Greenland National Park" (Table 1). All birds were breeding. In 2007 we captured 84 the birds on the nest using a bow net, while in 2006 they were captured within a few meters of the 
nest, using a small mist net (ca. one square meter) fixed on two handhold poles and rapidly raised in front of attacking birds.

All birds were equipped with 9.5g solar-powered PTTs from Microwave Telemetry Inc (Columbia, USA). Transmitters were attached to the birds as a backpack using Teflon ribbon and four silver rings to build the harness. The PTT and harness (ca. $2 \mathrm{~g}$ ) weighted less than $12 \mathrm{~g}$, which was on average 3.9\% ( $\pm 0.15 \mathrm{SD}$ ) of the body mass of the birds. The PTTs fitted on the two birds in 2006 were set to a constant duty cycle of 7/38h (on/off, respectively), the two PTTs attached in 2007 had a constant duty cycle of $7 / 25 \mathrm{~h}$ on/off.

PTTs were located using the Argos positioning system (CLS 2008) that provides positions in seven precision classes. The location errors of the classes called LC3, LC2, LC1 and LC0 follow a normal distribution with a standard deviation of $<150,<300,<1000$ and $>1000 \mathrm{~m}$ respectively. There is no accuracy estimate associated with the remaining classes (i.e. LCA, LCB and LCZ) but LCA have been showen to have the same accuracy as LC1 (Hays et al. 2001; Vincent et al. 2002). We used orthodromic distances to estimate the "daily rates of travel" of the birds (Imboden and Imboden 1972; James et al. 2005) for time scales of $45 \pm 7$ hours (in 2006) and $32 \pm 7$ hours (in 2007). For these calculations, we used successive "best daily location" (i.e. in order of preference: LC3, LC2, LC1, LCA, LC0) produced during the 7 hour transmitting period. We never used LCB and LCZ in the calculations. We also estimated "hourly rates of travel" using successive high accuracy fixes (LC3, LC2 and LC1) for time periods between 0.5-2 hours (for more details see Gilg et al. 2010).

\section{Results}

Altogether, the four PTTs produced 1019 Argos positions and the birds could be monitored for 45 to 86 days (mean 66 days; Table 1). Only one third (i.e. 376) of these locations were LC3, LC2, LC1 or LCA, but more than $70 \%$ of the "best daily positions" (i.e. 93 out of 131) were high accuracy fixes (LC3, LC2 and LC1).

Since 2006 and 2007 were two years with very low lemming densities in Mestersvig and Karupelv Valley, no Long-tailed Skuas bred successfully in either of these study sites during these years (Gilg et al. 2009; Benoit Sittler, unpublished data). The three birds monitored from this region left their breeding grounds 36-43 (Papikk), 42-43 (Niilar) and 12 days after they had been released (Table 1). The bird from Bliss Bugt (Blissy), the only bird that had possibly raised young (considering a fledging period of 25 days: Cramp and Simmons 1983), left its territory 31 days after release. 
117 occurred between July $19^{\text {th }}$ and August $15^{\text {th }}$, in line with previous studies (Korte 1984; Wiley and Lee 118 1998; Benoît Sittler and Olivier Gilg, unpublished data).

After departure, all birds moved southward following the outer coast (note that "Blissy" did not take the shortest route over the Greenland icecap), passing between southeast Greenland and Iceland, towards a large (ca. $500.000 \mathrm{~km}^{2}$ ) staging area located off the Great Banks of Newfoundland in Canada (Figure 1). The first bird (Lucy) arrived there by the end of July, the others by the end of August. With the exception of Blissy, which was lost 20 days after it had started its migration (i.e. shortly before reaching this area), it took the birds 1-2 weeks to travel the $3.000 \mathrm{~km}$ from their breeding grounds in Northeast Greenland to this staging area (Figure 1). The three birds then stayed in this area for 8-20 days.

Two of the remaining birds could be further followed while they crossed the Atlantic Ocean towards North-West Africa. It took them one week to travel the 2500-3000 km from the staging area to the African waters, north of the Madeira Archipelago, where they arrived on September $12^{\text {th }}$ (Papikk) and $23^{\text {rd }}$ (Niilar), i.e. 21 and 39 days respectively after they had left their breeding grounds. From there, the last bird we monitored (Papikk) continued to move south, flying a few 100's of km offshore, and was finally lost one week later and $2500 \mathrm{~km}$ further south, off the coast of Guinea (ca. $10^{\circ}$ Lat. N).

After they had left their breeding grounds, the rate of travel of the birds was usually between $100-400 \mathrm{~km} /$ day, with maximum rates of 800-900 km/day (Figure 2: upper panel). When adding together the daily legs of this route, the length of the post-breeding flyway, from Greenland to Guinea (through the Canadian waters -off the Great Banks- and the Madeira Archipelago) is about $10.000 \mathrm{~km}$ (Figure 2: central panel), and is $1500 \mathrm{~km}$ longer for birds like "Blissy" breeding in North Greenland.

138 The remaining distance to the main known wintering grounds (see Discussion) off South Africa is about $5000 \mathrm{~km}$ on a direct route crossing the Gulf of Guinea (according to Lambert (2006), some migrating Long-tailed Skuas follow the coast of Angola while other cross the Gulf of Guinea 141 offshore).

The hourly rate of travel calculated during migration with 63 successive pairs of high accuracy

143 fixes was $14 \mathrm{~km} / \mathrm{h}$ on average (maximum values: 53, 56 and $61 \mathrm{~km} / \mathrm{h}$ ). In several instances, we also

144 found evidence of active nocturnal migration, as already suspected by Lambert (1988). Two such cases 145 presented in detail in Table 2 (using four and six LC0 fixes) indicate that distances travelled during such events (i.e. $>200 \mathrm{~km}$ ), are not anecdotal when compared with the mean daily rate of travel

147 (Figure 2: upper panel). 


\section{Discussion}

150 Although our results are inferred from only four individuals, the consistency in the routes followed by

151 these birds, and the fact that they originated in three different locations over two different years,

152 supports the idea that the Long-tailed Skuas breeding in East and North Greenland use a specific post-

153 breeding flyway and make use of a staging area off the Canadian Great Banks between ca. $48-51^{\circ}$ Lat.

154 N (Figure 1 and Figure 2: see plateau on lower panel). This pelagic region is well known for its high

155 productivity (see e.g. http://oceancolor.gsfc.nasa.gov/SeaWiFS) and has also recently been suggested

156 as a "hot-spot" for other seabird species (Egevang et al. 2010; see also historical data in Wyne-

157 Edwards 1935). Staging in this area probably allows the Long-tailed Skuas to restore fat reserves after

158 the demanding breeding season before heading to the southern hemisphere through the low productive 159 tropical waters off West Africa.

From this staging area, Long-tailed Skuas head eastward, crossing the Atlantic Ocean north of 161 the Azores Islands and reaching Northwest Africa between mid August and late September. Only few 162 autumn observations have been made from the coasts of West Africa, probably because the migrating 163 birds pass far offshore (see Papikk and Niilar on Figure 1), but seawatching from the Cape Verde

164 Peninsula in Senegal has provided an average of 18 birds per day in October between 1995 and 2008

165 (111 days of monitoring and 1988 birds counted; Dubois et al. 2009), with a maximum of 123 birds on 16627 October 2007 (Nilsson 2008). Numbers are probably even higher in late August and September

167 (e.g. 69 Long-tailed Skuas counted in a single day the 31st of August 1990; Baillon and Dubois 1991;

168 see also Fig. 2 lower panel) but no regular monitoring has yet been undertaken during this period 169 (Dubois et al. 2009).

170 At first glance, our results would suggest that the Greenland birds migrate to the South-

171 African wintering zone, where large concentrations of this species have been reported in the past,

172 rather than to South-America, as previously thought by some authors (Harrison 1989; Olsen and

173 Larsson 1997; but see below). Lambert (1980) for example found great numbers of Long-tailed Skuas

174 off the coast of Namibia (> 200 birds some days) and Ryan (1989), working off the South African 175 coast, gave an estimate of 75.000 Long-tailed Skuas wintering between 34 and $44^{\circ}$ Lat. S. (see also 176 observations from Lambert (2006) who counted up to 26 birds per day in October/November off the 177 coast of Angola). Whether overestimated or not, these figures are at least suggesting that this region, a 178 highly productive marine area due to the Benguela upwelling system (Hutchings 1992), is a key 179 wintering area for the species. It probably hosts birds from many different origins, and possibly most if 180 not all of the western Palaearctic populations. 

continue their migration towards the other main wintering area reported in the Southern Atlantic Ocean: the Falkland current off Argentina. Up to 1500 birds were seen daily in this region in early November 1920 (Cramp 1985; Olsen and Larsson 1997), though later visits always provided much smaller numbers (Brown et al, 1975; Murphy 1936; Veit 1985; Wetmore 1926) or even failed to record the species at all (see e.g. Orgeira 2001; Tuck 1985). Among all known wintering areas for this species, the remaining ones only host small numbers of wintering birds and are less likely to be used by Greenland Long-tailed Skuas. For example the east coast of Africa (Lambert 2005) and the southwestern coast of South America (Harrison 1989; Howell and Webb 1995; Johnson 1965; Tuck and Heinzel 1985), another region with productive upwelling zones, are thought to host birds originating from central Siberia (Lambert (2005) suggested that these birds use overland migration) and from eastern Siberia-Alaska, respectively. A few additional wintering areas may exist, e.g. off Australia and New Zealand, as suggested by irregular but repeated observations (Harrison 1989; Lewis 1991; Marchant and Higgins 1996; Melville 1985; Olsen and Larsson 1997; Wood 1989), and the species may even winter in the sub-Antarctic region where it has been seen from boats (Kampp 2001). with the Sabine's Gull (Larus sabini; Olsen and Larsson 1997), which has a similar circumpolar breeding range. It is also interesting to note that the post-breeding flyway of the East Greenland Longtailed Skuas greatly overlaps with the one recently documented for 11 Arctic Terns (Sterna paradisaea) originating from the same region (Egevang et al. 2010). While most of these birds $(n=7)$ moved along the African Coast heading to South Africa, four of these Terns crossed the Atlantic using an alternate flyway towards the coast of Brazil. Such a bi-directional migration pattern might also exist for the Long-tailed Skuas originating from the North Atlantic sector and would explain the records made off South America (see above). Indeed and as suggested above, after reaching the tropical waters off West Africa, some birds could make use of favourable easterly winds to continue westward (see Felicísimo et al. 2008), hence following a "S-shape" flyway from breeding to wintering grounds. Based on this review and considering our limited knowledge of the migration patterns and

208 wintering areas of the Long-tailed Skua, it is obvious that if we want to document the different 209 flyways and assess the exact borders and respective importance of the different wintering grounds, we 210 should continue our efforts and initiate sister projects over the entire breeding range of the species. To 211 date, Southwest Africa and Southeast South-America appear to be the two main wintering grounds for 212 this species, but the relative importance of these areas is still unclear. 
214 a few weeks. Overcoming these difficulties, for example using geolocators (Egevang et al. 2010),

215 would open new perspectives and may also shed new light on the spring migration which, according to

216 Lambert's (1980) observations (he still noticed adult birds off Namibia in early May, i.e. one month

217 only before they arrive on their breeding grounds), could be much faster than the autumn migration

218 (i.e. $\geq 12.000 \mathrm{~km}$ in only one month).

\section{Acknowledegments}

We are grateful to the Groupe de Recherche en Ecologie Arctique and the Musée d'histoire naturelle de Fribourg for financial support, to Pascal Grand, Brigitte Sabard and Luc Hardy for their help in the field, to the Government of Greenland (Ministry of Domestic Affairs, Nature and Environment) for granting access and research permits in the "North and East Greenland National Park", and to Ross Bartley for his comments on an earlier draft of the manuscript.

\section{Bibliography}

228 Andersson M (1971) Breeding behaviour of the Long-tailed Skua Stercorarius longicaudus (Vieillot). Ornis Scand 2:35-54

Andersson M (1976) Population ecology of the Long-Tailed Skua (Stercorarius longicaudus Vieill.). J Anim Ecol 45:537-559

Andersson M (1981) Reproductive tactics of the long-tailed skua Stercorarius longicaudus. Oikos $37: 287-294$

234 Baillon F, Dubois P (1991) Seawatching from Cape Verde, Senegal. Birding World 4:440-442

235 CLS (2008) Argos User's Manual. CLS, Toulouse

236 Coyne MS, Godley BJ (2005) Satellite Tracking and Analysis Tool (STAT): an integrated system for archiving, analyzing and mapping animal tracking data. Marine Ecology-Progress Series $301: 1-7$

Cramp S (1985) Handbook of the birds of Europe, the Middle East and North Africa. Volume IV Terns to woodpeckers. Oxford University Press, Oxford

Cramp S, Simmons KEL (1983) Handbook of the birds of Europe, the Middle East and North Africa. 
Egevang C, Stenhouse IJ, Phillips RA, Petersen A, Fox JW, Silk JRD (2010) Tracking of Arctic terns Sterna paradisaea reveals longest animal migration. PNAS 107:2078-2081

247 Felicísimo AM, Munñoz J, González-Solis J (2008) Ocean Surface Winds Drive Dynamics of Transoceanic Aerial Movements. PLoS ONE 3:e2928

249 Furness RW (1987) The Skuas. Poyser, Calton

250 Furness RW, Crane JE, Bearhop S et al (2006) Techniques to link individual migration patterns of seabirds with diet specialization, condition and breeding performance. Ardea 94:631-638

Gilg O (2002) The summer decline of the collared lemming (Dicrostonyx groenlandicus) in high arctic Greenland. Oikos 99:499-510

Gilg O, Hanski I, Sittler B (2003) Cyclic dynamics in a simple vertebrate predator-prey community. Science 302:866-868

Gilg O, Sittler B, Hanski I (2009) Climate change and cyclic predator-prey population dynamics in the high-Arctic. Global Change Biol 15:2634-2652

Gilg O, Sittler B, Sabard B, Hurstel A, Sané R, Delattre P, Hanski I (2006) Functional and numerical responses of four lemming predators in high arctic Greenland. Oikos 113:196-213

Gilg O, Strøm H, Aebischer A, Gavrilo MV, Volkov A, Miljeteig C, Sabard B (2010) Post-breeding movements of the northeast Atlantic ivory gull Pagophila eburnea populations. Journal of Avian Biology 41:532-542

Harrison P (1989) Seabirds. Christopher Helm, London

Hays GC, Åkesson S, Godley BJ, Luschi P, Santidrian P (2001) The implications of location accuracy for the interpretation of satellite-tracking data. Anim Behav 61:1035-1040

Howell SNG, Webb S (1995) Noteworthy bird observations from Chile. Bull Brit Orn Club 115:57-66

Hutchings L (1992) Fish harvesting in a variable, productive environment — searching for rules or searching for exceptions? S Afr J Mar Sc 12:297-318

Imboden C, Imboden D (1972) Formel für Orthodrome und Loxodrome bei der Berechnung von Richtung und Distanz zwischen Beringungs- und Wiederfundort. Vogelwarte 26:336-346 James MC, Eckert SA, Myers RA (2005) Migratory and reproductive movements of male leatherback turtles (Dermochelys coriacea). Mar Biol 147:845-853 
Kampp K (2001) Seabird observations from the South and Central Atlantic Ocean, Antarctica to $30^{\circ} \mathrm{N}$, March-April 1998 and 2000. Atlantic Seabirds 3:1-14

277 Korte Jd (1984) Ecology of the Long-tailed Skua (Stercorarius longicaudus Vieillot, 1819) at Scoresby Sund, East Greenland. Part two: Arrival, Site tenacity and Departure. Beaufortia $34: 1-14$

Korte Jd (1985) Ecology of the Long-tailed Skua, Stercorarius longicaudus Vieillot, 1819, at Scoresby Sund, East Greenland. Part three: clutch size, laying date and incubation in relation to energy reserves. Beaufortia 35:93-127

Lambert K (1980) Ein Überwinterungsgebiet der Falkenraubmöwe, Stercorarius longicaudus Vieill. 1819, vor Südwest- und Südafrika entdeckt. Beitr Vogelkunde 26:199-212

Lambert K (1988) Nächtlichte Zugaktivität von Seevögeln im Golf von Guinea. Beitr Vogelkunde 34:29-35

Lambert K (2005) The spatial and seasonal occurence of seabirds (Aves) off southern Mozambique. Durban Museum Novitates 30:45-60

Lambert K (2006) Seabird sightings in the waters off Angola, 1966-1988. Marine Ornithology 34:7780

Larson R (2007) Site tenacity of the Long-tailed Skua Stercorarius longicaudus - a study of the population at Stekenjokk. Ornis Svecica 17:81-89

Lewis M (1991) The status of long-tailed jaeger Stercorarius longicaudus in Australian waters. Austr Bird Watcher 14:119-122

Maher WJ (1970) Ecology of the Long-tailed Jaeger at Lake Hazen, Ellesmere Island. Arctic 23:112-

Marchant S, Higgins PJ (1996) Handbook of Australian, New Zealand and Antarctic birds. Vol. 3. Pratincoles to Pigeons. Oxford University Press, Melbourne

Meltofte H, Høye TT (2007) Reproductive response to fluctuating lemming density and climate of the Long-tailed Skua Stercorarius longicaudus at Zackenberg, Northeast Greenland, 1996-2006. Dansk Orn Foren Tidsskr 101:109-119

Melville DS (1985) Long-tailed skuas Stercorarius longicaudus in New Zealand. Notornis 32:51-73

304 Nilsson K (2008) Senegal - Havsfågelskådning i världsklass. Vår Fågelvärld 5/2008:18-21 
Orgeira JL (2001) Distributión especial de densidades de aves marinas en la platforma continental Argentina y Océano Atlantico sur. Ornitologia Neotropical 12:45-55

Ryan PG (1989) The distribution and abundance of Long-tailed Skuas off southern Africa. Ostrich 60:89-90

Schmidt NM, Berg TB, Forchhammer M, Hendrichsen DK, Kyhn LA, Meltofte H, Høye TT (2008) Vertebrate predator-prey interactions in a seasonal environment. Adv Ecol Res 40:345-370

Sittler B (1995) Response of stoat (Mustela erminea) to a fluctuating lemming (Dicrostonyx groenlandicus) population in North East Greenland: preliminary results from a long term study. Ann Zool Fennici 32:79-92

315 Tuck G (1985) A guide to seabirds on the ocean routes. Collins, London

316 Tuck G, Heinzel H (1985) Guide des oiseaux de mer. Delachaux et Niestlé, Neuchâtel

317 Veit RR (1985) Long-tailed jaegers wintering along the Falkland Current. Amer Birds 39:873-878

318 Vincent C, McConnell BJ, Ridoux V, Fedak MA (2002) Assessment of Argos location accuracy from satellite tags deployed on captive gray seals. Mar Mamm Sci 18:156-166

Wetmore A (1926) Observations on the birds of Argentina, Paraguay, Uruguay, and Chile. US Natl Mus Bull 133

322 Wiley RH, Lee DS (1998) Long-tailed Jaeger (Stercorarius longicaudus). In: Poole A (ed) The Birds of North America Online, Cornell Lab of Ornithology; Retrieved from the Birds of North America Online: http://bna.birds.cornell.edu/bna/species/365, Ithaca

Wood KA (1989) Seasonal abundance, marine habitats and behaviour of skuas of central New South Wales. Corella 13:97-104

327 Wyne-Edwards VC (1935) On the habits and distribution of birds on the North Atlantic. Proceedings of the Boston Society of Natural History 40:233-346 
331 Table 1: Summary data for the four studied Long-tailed Skuas and timing of their post-breeding

332 migration

333

334

\begin{tabular}{|c|c|c|c|c|c|c|}
\hline $\begin{array}{l}\text { Birds' } \\
\text { names } \\
\text { (mass) }\end{array}$ & $\begin{array}{c}\text { Trapping location } \\
\text { (deg. Lat.N/Long. W) }\end{array}$ & $\begin{array}{c}\text { Release } \\
\text { date }\end{array}$ & $\begin{array}{l}\text { Duration of } \\
\text { tracking }\end{array}$ & $\begin{array}{l}\text { Start date of } \\
\text { fall migration } \\
\text { in Greenland }\end{array}$ & $\begin{array}{c}\text { Duration of } \\
\text { staging off } \\
\text { Canada }\end{array}$ & $\begin{array}{c}\text { Arrival off } N W \\
\text { Africa }\end{array}$ \\
\hline $\begin{array}{l}\text { Papikk } \\
\text { (300g) }\end{array}$ & $\begin{array}{l}\text { Karupelv Valley } \\
\qquad\left(72.50^{\circ} / 24^{\circ}\right)\end{array}$ & $30-6-2006$ & 81 days & 5-12 August & 8 days & $12-9-06$ \\
\hline $\begin{array}{l}\text { Niilar } \\
(280 g)\end{array}$ & $\begin{array}{l}\text { Karupelv Valley } \\
\left(72.50^{\circ} / 24^{\circ}\right)\end{array}$ & $3-7-2006$ & 86 days & 14-15 August & 16 days & $23-9-06$ \\
\hline $\begin{array}{l}\text { Lucy } \\
(278 g)\end{array}$ & $\begin{array}{l}\text { Mestersvig } \\
\left(72.25^{\circ} / 24^{\circ}\right)\end{array}$ & $2-7-2007$ & 45 days & 19 July $^{2}$ & 20 days & n.d. \\
\hline $\begin{array}{l}\text { Blissy } \\
(295 g)\end{array}$ & $\begin{array}{c}\text { Bliss Bugt } \\
\left(83.57^{\circ} / 30^{\circ}\right)\end{array}$ & 8-7-2007 & 52 days & 8 August & n.d. & n.d. \\
\hline
\end{tabular}

$335{ }^{1}$ the earliest and latest possible departure dates from breeding grounds are given when the exact data could not 336 be documented

$3372^{2}$ this bird left its breeding territory on the $9^{\text {th }}$ of July but remained within $50-100 \mathrm{~km}$ of this area until July 18 . 
339 Table 2: Evidences for nocturnal migration of Long-tailed Skua.

340

\begin{tabular}{|c|c|c|c|c|c|c|c|}
\hline Bird & Date & $\begin{array}{l}\text { Latitude } \\
(\text { deg. } N)\end{array}$ & $\begin{array}{c}\text { Longitude } \\
\text { (deg. W) }\end{array}$ & $\begin{array}{l}\text { Solar } \\
\text { time }\end{array}$ & $\begin{array}{c}\text { Solar angle } \\
\text { (deg./horizon) }\end{array}$ & $\begin{array}{c}\text { Distance } \\
\quad(\mathrm{km})\end{array}$ & $\begin{array}{l}\text { Speed } \\
(\mathrm{km} / \mathrm{h})\end{array}$ \\
\hline \multirow[t]{4}{*}{ Papikk } & $12-13 / 09 / 06$ & $35.29^{\circ}$ & $15.16^{\circ}$ & $22: 12: 37$ & -43 & \multirow{4}{*}{$\begin{array}{l}50 \\
89 \\
96\end{array}$} & \multirow{4}{*}{$\begin{array}{l}30 \\
53 \\
62\end{array}$} \\
\hline & & $34.87^{\circ}$ & $15.33^{\circ}$ & $23: 51: 30$ & -51 & & \\
\hline & & $34.10^{\circ}$ & $15.06^{\circ}$ & $01: 33: 29$ & -46 & & \\
\hline & & $33.30^{\circ}$ & $14.70^{\circ}$ & 03:07:38 & -32 & & \\
\hline \multirow[t]{6}{*}{ Lucy } & $14-15 / 08 / 07$ & $43.63^{\circ}$ & $33.28^{\circ}$ & $19: 59: 43$ & -10 & \multirow{6}{*}{$\begin{array}{l}62 \\
12 \\
62 \\
16 \\
57\end{array}$} & \multirow{6}{*}{$\begin{array}{l}37 \\
37 \\
45 \\
55 \\
36\end{array}$} \\
\hline & & $43.23^{\circ}$ & $32.74^{\circ}$ & $21: 41: 41$ & -24 & & \\
\hline & & $43.17^{\circ}$ & $32.62^{\circ}$ & 22:00:59 & -26 & & \\
\hline & & $42.84^{\circ}$ & $32.00^{\circ}$ & $23: 26: 00$ & -32 & & \\
\hline & & $42.76^{\circ}$ & $31.84^{\circ}$ & $23: 44: 34$ & -33 & & \\
\hline & & $42.58^{\circ}$ & $31.19^{\circ}$ & $01: 20: 42$ & -30 & & \\
\hline
\end{tabular}


Fig. 1: Post-breeding flyway of four Long-tailed Skuas from North and East Greenland to West Africa (Papikk: square; Niilar: circle; Lucy: diamond and Blissy: triangle; details in Table 1). The background map is a transverse mercator projection between $0-85^{\circ}$ Lat. North and $0-60^{\circ}$ Long. West (www.seaturtle.org/maptool; Coyne and Godley 2005). Only the best daily locations (i.e. one position per day per bird) presented on the tracks (see Methods).

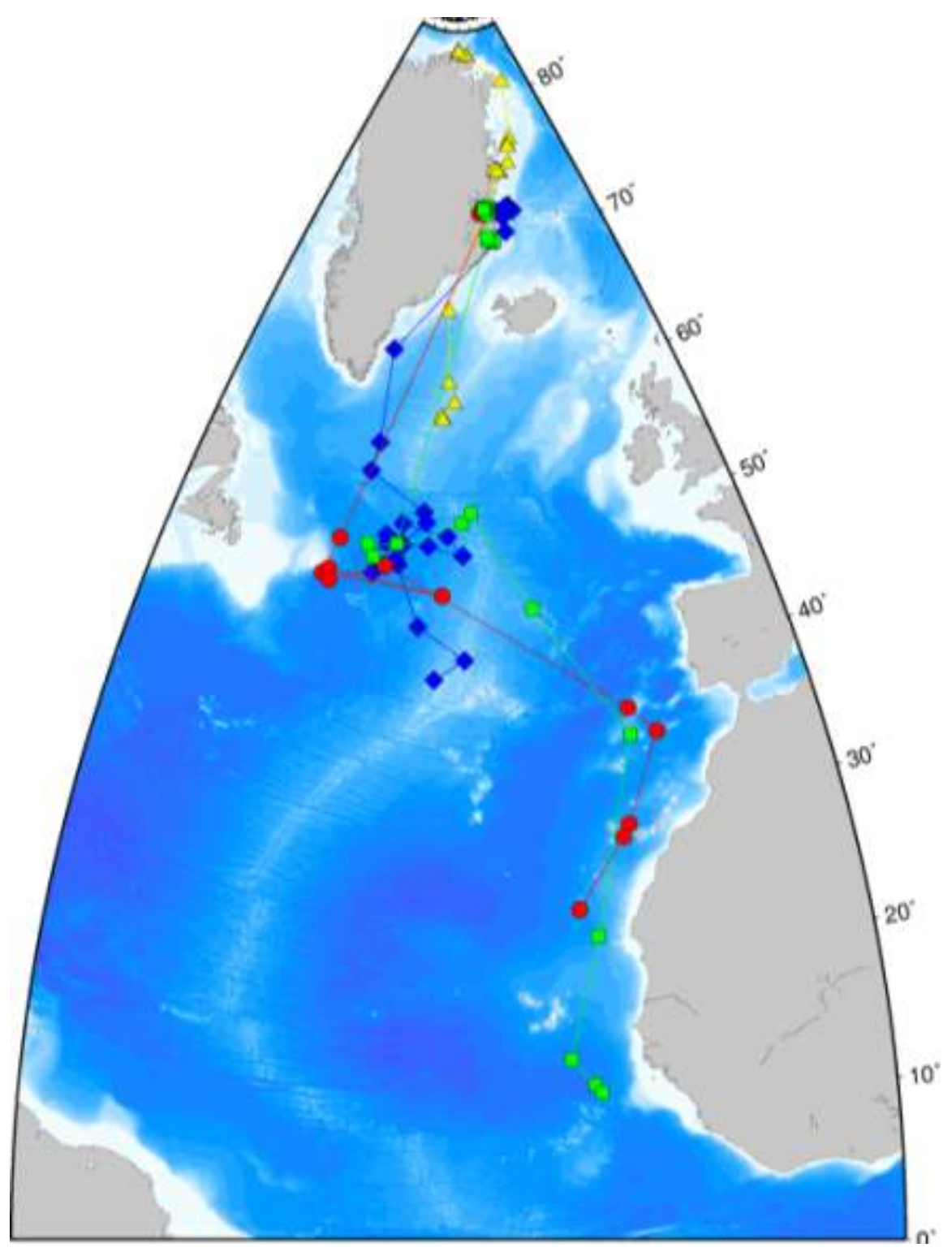


Fig. 2: Movements of four Long-tailed Skuas (Papikk: black circle; Niilar: open circle; Lucy: black diamond and hours (in 2006; circles) and 32 \pm 7 hours (in 2007; diamonds; see Methods).

355

356

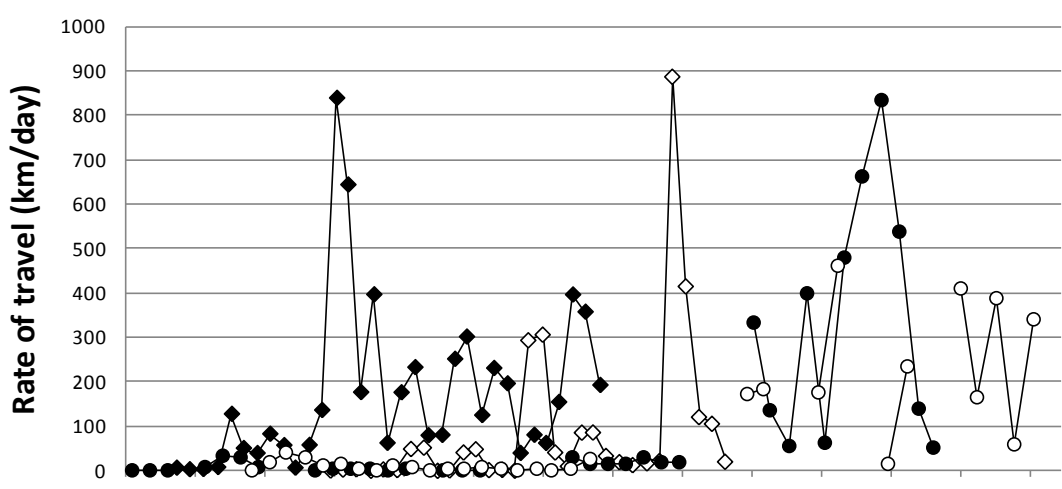

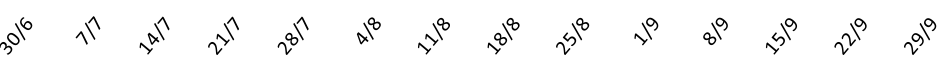
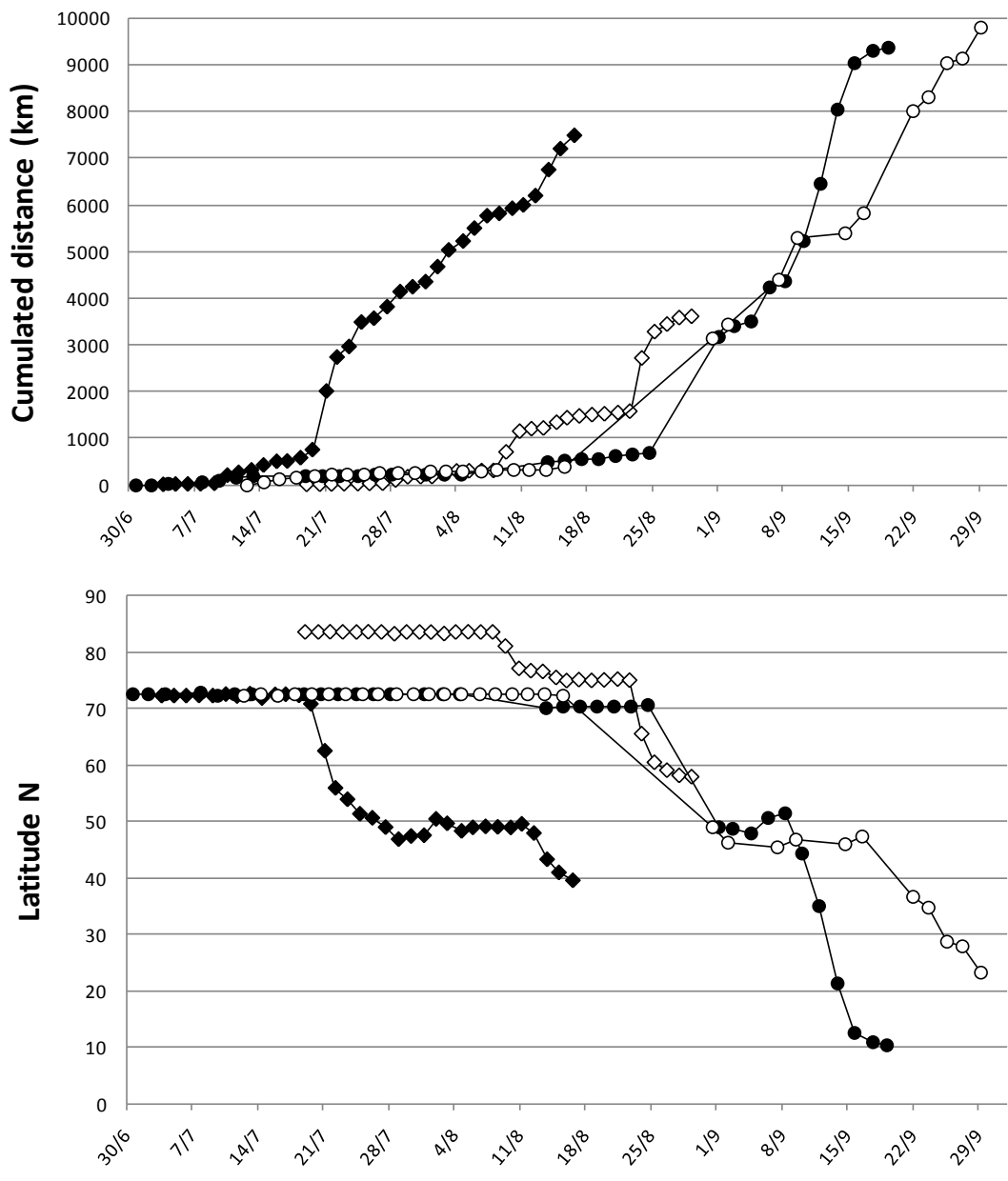